\title{
'Communicating Europe': The Role of Organised Civil Society
}

\section{Elizabeth Monaghan}

\begin{abstract}
The European Commission's new 'communication strategy' has been presented as a radically new way of bridging the gap between the citizens of the member states and the European Union (EU) institutions. However it should also be seen as the latest in a long line of attempts to solve the problems of democratic legitimacy from which the EU is said to suffer. The rhetoric of the strategy is infused with highly commendable objectives and desirable principles stating how effective communication can help the EU connect more closely with citizens, and calling upon all relevant stakeholders - specifically civil society - to contribute to this project. Democratic theories of civil society provide support for the idea that civil society can play a linkage role between citizens and political structures. But empirical research on processes of interest representation in the EU casts doubt on whether organisations purporting to represent various strands within European civil society are able and willing to help bring citizens and the EU closer together. Turning the empirical focus to the organisations themselves it becomes apparent that simply invoking civil society involvement in 'communicating Europe' is not a sufficient guarantee of success. Instead, the nature of the communication activities, the characteristics of the organisations in question, and the issue of funding all have implications for the role of civil society in communicating Europe.
\end{abstract}

SINCE 2005, A DISTINCT AND OSTENSIBLY NEW STRATEGY FOR 'COMMUNICATING EUROPE' has emerged from the European Commission, under the guidance of the Vice President and Commissioner for Institutional Relations and Communication Strategy, Margot Wallström. The key components of the strategy are the 2006 White Paper on a European Communication Policy which proposed an agenda for better communication in Europe; the Commission's contribution to the period of reflection - prompted by the rejection of the constitutional treaty by voters in France and The Netherlands in 2005 - the so-called 'Plan D for Democracy, Dialogue and Debate', published in 2005; and 'Communicating Europe in Partnership', the report presented to the European Parliament and Council by the Commission in October 2007. The Commission has been at pains to emphasise that the communication strategy is a genuinely new endeavour which involves connecting with the citizens in a radically different way than has been the case in the past. Yet this strategy can also be seen as the latest in a long line of attempts dating from the aftermath of the Maastricht Treaty to address the divergence between the political institutions of the European Union (EU) and the ordinary citizens living in the member states.

At the core of the communication strategy is an attempt to strengthen the democratic legitimacy of EU governance by bringing $\mathrm{EU}$ institutions and governance structures closer to citizens. Since Maastricht, there has been recognition in both academic and political circles, that a 'gap' has emerged between political elites and ordinary citizens - a gap which seems to be problematic for the continuation and consolidation of EU politics and integration. An increased capacity and willingness on the part of citizens to stall the integration process (Andersen \& Kaltenhaler 1996; Niedermayer \& Sinnott 1995; Hooghe 2003), has undermined the presumption of a 'permissive consensus' (Lindberg \& Scheingold 1971) of European publics and prompted suggestions that the EU suffers from a 'legitimacy deficit' (see Scharpf 1997; Abromeit 1998; Beetham \& Lord 1998; Eriksen \& Fossum 2000; Føllesdal 2004). The 
Commission recognises the emergence of this gap between the European Union and its citizens, pointing out in the Communication White Paper that as integration has been driven forward, communication with citizens has been left behind (Commission 2006a: 2). The aim of the communication strategy therefore, has been to work towards closing this gap.

A key component of the communication strategy has been the attempt to enlist the help of 'civil society' in the process of communicating Europe. Ideas found within democratic theory confirm that civil society can play a linkage role between citizens and the state, helping to bring the two closer together, and in doing so, enhancing the democratic legitimacy of governance structures. In practice, the proposals of the communication strategy have been directed at certain organisations which purport to represent sections within civil society. Although organisations representing various sections of civil society have for a long time been important actors in the EU system, their contribution has generally been seen in terms of policy outcomes and how they allow the development of effective and implementable policies - in the words of Scharpf, the EU's 'output legitimacy' (1998). In contrast, their contribution to improving the 'input legitimacy' of the EU, in other words the extent to which the genuine preferences of citizens are brought into the political process, is increasingly recognised but largely under-researched and under-theorised. The communication strategy is one example of the growing propensity on the part of the institutions to identify civil society as a means for strengthening the input legitimacy of the EU which is matched by an emerging theoretical and empirical literature (see De Schutter 2002; Smismans 2003 and contributions to Smismans 2006).

In seizing upon civil society as a crucial actor in the process of communicating Europe, the Commission relies upon an additional set of actors to guarantee the success of the communication strategy. Taking a closer look at the kind of organisations involved it becomes apparent that they do not always have the capacity, let alone the willingness, to engage in communication activities that would help to bridge the gap between citizens and EU institutions. In the following analysis I draw upon interviews conducted with a range of organisations that were involved in a previous legitimacy-enhancing strategy: the debate on the future of the EU. ${ }^{1}$ The responses of these organisations point towards three issues that are likely to govern the role of organised civil society in communicating Europe, and are therefore potentially fundamental to the success (or otherwise) of the communication strategy.

First, there are issues surrounding the exact nature of the communication that is proposed by the strategy, or in other words, the substantive activity of communication. I suggest that there is a need for the exact nature and purpose of the communication activities to be specified, and to be matched to the capacities of the organisations involved. Second, the characteristics of the organisations are crucial. The term 'civil society' hides a great deal of diversity found among the organisations, which include trade unions, non-governmental organisations (NGOs), think-tanks and regional organisations, each of which may be suited to the task of communicating Europe in different ways. Third, the issue of funding is prominent in discussions with civil society organisations and has significant implications for their capacity, and their willingness to engage in communication activities. Before assessing these factors I outline in greater detail some of the key components of the communication strategy, and then take a closer look at the contribution of EU civil society to bridging the gap between citizens and EU institutions, or in other words, strengthening the democratic legitimacy of EU governance.

\footnotetext{
${ }^{1}$ There are important similarities between the post-Laeken debate on the future of the EU initiative and the communication strategy. Both strategies have had at their core, an attempt to strengthen the legitimacy, particularly the 'input' legitimacy of the EU, based on the premise of a gap that had emerged, and emphasising the need to overcome this by 'bringing the EU institutions and its citizens closer together'. A further similarity between the debate initiative and the communication strategy is that they both turn towards civil society in their attempts to find the solution to the legitimacy problem. These similarities mean that in practical terms, lessons can be drawn from the experiences of civil society organisations involved in the debate initiative for the communication strategy.
} 


\section{The Commission's 'communication strategy'}

Communication was established as one of the Barroso Commission's strategic objectives when it began its term of office in 2004, and as a policy in its own right, exemplified by the appointment of the first ever Commissioner for Communication Strategy. The communication strategy which has since emerged has been constructed around several important documents: the 'Action Plan' to improve communicating Europe by the Commission (European Commission 2005a); the Commission's contribution to the period of reflection and beyond: 'Plan D for Democracy, Dialogue and Debate' (European Commission 2005b); and the 'White Paper on a European Communication Policy' (European Commission 2006a); known hereafter as the 2005 Action Plan, Plan D; and the Communication White Paper respectively. In October 2007 the Commission followed up these initiatives with the publication of the report 'Communicating Europe in Partnership' (European Commission 2007).

The Action Plan to Improve Communicating Europe by the Commission (European Commission 2005a) was presented by Margot Wallström in July 2005, shortly after the referendums on the Constitutional Treaty in France and the Netherlands. The objective of the Action Plan was to encourage the Commission to 'put its own house in order' so as to allow more effective communication about Europe (European Commission 2005a: 2), based on the recognition that, even within the Commission, there were multiple, and not always complementary approaches to communicating with citizens and the outside world more generally. In doing so it pointed towards the publication of the White Paper on Communication which would set out the policy vision and initiatives to be undertaken in cooperation with the other stakeholders. The Action Plan defined three strategic principles which aimed to put citizens at the heart of communication: Listening, Communicating and Connecting with Citizens by 'going local'. The principle of listening established that communication is 'not a one-way street'; that it is not just about informing citizens, but also about citizens expressing their opinions so the Commission can understand. The intention was that the voice of citizens could have a direct bearing on EU policy formulation and output. Communication, the second strategic principle, stated that EU policies and their impact on people's everyday lives must be communicated and advocated in a way that people can understand. Finally, 'going local' meant that communication activities should be related to particular national and local concerns; delivered in a language that people can understand; and via the medium they preferred.

These strategic principles informed the Communication White Paper which was published on $1^{\text {st }}$ February 2006. The commitment to listening was expressed in terms of the intention to 'move away from one-way communication to reinforced dialogue, from an institutioncentred to a citizen-centred communication, from a Brussels-based to a more decentralised approach' (European Commission 2006a: 4). The Commission presented this as a break with the past, a fundamentally different way of communicating than had previously characterised communication processes. Some tentative suggestions for how this might be achieved were offered in the White Paper, for instance by 'defining common principles', and 'empowering citizens', thereby addressing the ways in which EU policies were advocated and communicated. Furthermore, in order to achieve the communication objectives the White Paper spelt out the importance of partnerships with all the key players, namely other EU institutions, national, regional and local authorities, political parties and civil society; and the use of the media and new technologies.

In between the adoption of the Action Plan and the publication of the White Paper the Commission had launched 'Plan D for Democracy, Dialogue and Debate' in October 2005. Plan D was in part a contribution to the 'period of reflection' called by the Heads of State and government following the rejection of the Constitutional Treaty in France and The Netherlands. The Commission argued that the period of reflection should be used for a broad and intensive debate on European policies which would allow the development of a clear view of citizens' needs and expectations vis-à-vis the European Union. Plan D, it argued, would not be limited to the period of reflection (which in the end ran up until the European 
Council meeting of June 2007 at which the decision was taken to draw up a new 'reform' treaty), but rather would run for the lifetime of the Barroso Commission and beyond. Plan D dovetailed with the Action Plan and White Paper and together with them, aimed to help set out a long-term plan to reinvigorate European democracy and help the emergence of a 'European public sphere' (European Commission 2005b: 2). This in turn would, it hoped, seek to 'clarify, deepen and legitimise a new consensus on Europe and address criticisms and find solutions where expectations have not been met' (European Commission 2005b: 11). In its initial phase, Plan D launched six transnational projects aimed at providing opportunities for citizens to engage in debates about Europe hosted by civil society organisations, culminating in a meeting of 250 citizens in Brussels in December 2007.

The Action Plan, the Communication White Paper, and Plan D informed the subsequent proposal, made by the Commission in 'Communicating Europe in Partnership', for an InterInstitutional Agreement (IIA) on communication (European Commission 2007: 4). This report, addressed to the Council and the European Parliament, was presented by the Commission as a first step in translating the ideas that had already been discussed into concrete proposals. It argued that the public required a more integrated approach to communication from the various institutions of the EU - and the absence of this made the EU seem disorganised, dispersed and difficult to understand. As such it identified concrete examples of where the institutions could work together, for instance through better co-ordination of the Representations of the Commission in the member states, and the European Parliament's Information Offices (2007: 8).

Together, these documents, and the various speeches and reports that have accompanied them, have contributed to the construction of a discourse on the centrality of citizens to discussions about EU policy and the future direction of European integration. As such, they have operated largely at the level of rhetoric, and have been vague on the details of how exactly effective communication could bridge the gap between citizens and the EU. Although 'Communicating Europe in Partnership' has gone further in making more concrete proposals regarding the role of the EU institutions and member state governments, it does not contain a clear statement on the role of civil society. In addition, much of the responsibility for implementing the proposal discussed in this report, much like Plan D and the Communication White Paper, has been placed with actors other than the Commission: regional and local authorities, other EU institutions, political parties, and member state governments (as well as civil society organisations).

The Commission, and particularly Margot Wallström, has emphasised that this strategy is a new approach to European communication, but it should be seen as the continuation of a longer-term strategy to connect more closely with European citizens through communication. The difficulties surrounding the ratification of the Maastricht Treaty highlighted that there was a gap between the political elites who were driving forward the process of integration, and the feelings of many ordinary citizens: feelings characterised by high levels of public ignorance about and even hostility towards the EU. With this realisation came an acceptance in principle that informing the public about, and involving them in the process of integration was necessary. Following the report of a 'reflection group' set up to assess the information and communication policies of the EU, the Commission decided that its lack of public support was largely due to inadequate information and understanding and so endeavoured to increase the transparency of its policy making. Further integration was to be 'based on information, which means giving the facts and explaining, communication which means listening and dialogue, and transparency, which means priority to total openness in pursuing the first two objectives' (European Commission 1994).

More recently, the Commission adopted a communication in June 2001 for a new framework on activities concerning the information and communication policy of the EU (European Commission 2001b) which called upon the other EU institutions and the member state governments to contribute to this approach. This was followed by the publication of an information and communication strategy for the EU in October 2002 (European Commission 2002). Neither of these could be said to have solved the communication challenges faced by 
the EU, despite the fact that, like the more recent communication strategy, they also emphasised 'the need for a fresh approach' (European Commission 2002: 8) and 'genuine dialogue' (European Commission 2002: 10).

The current communication strategy elaborated in the 2005 Action Plan, Plan D, the Communication White Paper and 'Communicating Europe in Partnership', also bears a striking resemblance in terms of the rhetoric used, with the Governance debate surrounding the Commission's 2001 White Paper, and the debate on the future of the EU, surrounding the Constitutional Treaty. Like the Governance debate and the debate on the future of the EU, the current communication strategy is motivated by the need for stronger democratic legitimacy. A further significant similarity is the emphasis on the role played by various stakeholders in implementing the strategy and in particular organised civil society. These similarities suggest that the experience of civil society organisations can provide lessons for the communication strategy as I argue later, but first the treatment of 'civil society' in the rhetoric of the communication strategy is considered.

\section{Civil society, communication and legitimate governance}

The new communication strategy outlines an important role for civil society in helping to 'communicate Europe'. Once again, there are elements of continuity with previous reform strategies, rather than the break with the past that the rhetoric of the Communication White Paper suggests. This interest in civil society should be seen in the context of a broader tendency among politicians to look for solutions to democratic problems, and one which is not confined to the EU setting. Throughout the 1980s and 1990s the idea of civil society was seized upon as a means of strengthening democracy ${ }^{2}$ (for an overview of this academic literature see Foley \& Edwards 1997; Young 2000; Diamond 1996). Civil society is seen as able to provide something, or play a role which formal political authorities cannot. In the EU context, the role of civil society has often been expressed in terms of closing the gap between EU politics and ordinary citizens, and has been invoked to indicate that the EU institutions acting alone cannot solve the EU's legitimacy problems. The Commission acknowledged this in the 2001 Governance White Paper which stated that 'the Commission alone cannot improve European governance...change requires concerted action by all the European institutions, present and future member states, regional and local authorities and civil society' (European Commission 2001a: 9).

The 2005 Action Plan said little about the role of civil society, its focus being to address communication structures within the Commission. However in outlining the strategic principles of listening, communicating and going local it paved the way for the White Paper which had a much broader focus and which addressed a wider audience. Civil society featured prominently in the Communication White Paper and was identified early on as crucial to ensuring the success of the strategy. Civil society is viewed in terms of a series of organisations that have a 'very important role to play in raising public awareness of European issues and policy debates, and in encouraging people to take an active part in those debates' (European Commission 2006a: 12). The Communication White Paper did not define civil society explicitly, beyond stating that it includes 'professional and sectoral organisations (2006a: 12). ${ }^{3} \quad$ Furthermore, it gave no concrete examples of how this role might be operationalised beyond suggesting 'targeted co-operation projects in the field of public communication'.

\footnotetext{
2 Of course, the notion of civil society did not originate in the 1980s. Diamond (1996: 227) traces the theoretical origins of the concept to Alexis de Tocqueville and argues that it is 'emotionally and spiritually indebted to Jean-Jacques Rousseau for its romanticization of "the people" as a force for collective good'.

${ }^{3}$ But we can assume that the definition specified in the 2001 Governance White Paper is applicable here: 'civil society includes the following: trade unions and employers' associations ("social partners"); nongovernmental organisations; professional associations; charities; grass-roots organisations; organisations that involve citizens in local and municipal life with a particular contribution from churches and religious communities' (European Commission 2001a: 14).
} 
Plan D took the issue of civil society involvement in 'communicating Europe' further. The initial Plan D document, which was presented by the Commission to the Council, the Parliament, the Economic and Social Committee and the Committee of the Regions, said very little about the role of organised civil society. However, a subsequent call for proposals relating to the implementation of Plan D went into greater detail. The call offered 'financial support for initiatives emanating from European organisations to promote public participation in debates on topics of European interest' (2006b: 1), the role of these being to stimulate discussion and seek recognition for the added value that the European Union can provide. This call resulted in six transnational projects which aimed to get citizens involved in discussions about the EU (or in the words of the Commission's 'communicating Europe' website, to 'experiment active citizenship').

In 'Communicating Europe in Partnership', the Commission discussed the interactions between the EU institutions at greater length than the role of civil society. It did, however, outline the need to establish partnerships with NGOs in order to communicate on subjects of general interest such as climate change (European Commission 2007: 6). It is not obvious how these partnerships would be formed or what they would look like, but no further discussion of this particular proposal was included. Elsewhere in the report it is unclear whether the proposals referred to the Commission communicating to civil society and the public, or whether civil society organisations would assist the Commission in communicating to the public - or both (European Commission 2007: 7-8). So whilst this component of the communication strategy goes further than the others in translating rhetoric into concrete actions, it does not go as far as making a clear statement on the role of civil society in communicating Europe.

In these various components of the communication strategy, the term 'civil society' actually refers to the organisations that populate the space between citizens and the state - what can be described more specifically as 'organised civil society'. The EU institutions have a history of working with organisations of civil society, though in the past they were not called 'civil society' actors. Instead they were referred to as 'organised interests' and the purpose of their involvement in EU politics was to provide expertise in the policy-making process. An extensive research literature documented processes of EU interest representation and the role played by these organisations in helping to make and implement effective, efficient policies (key contributions include Greenwood 2003b, 2007b; Mazey \& Richardson 1993, 1999; Warleigh \& Fairbrass 2002). The extent to which these processes helped to bridge the gap between citizens and EU politics, or more generally helped to strengthen legitimate EU governance, tended not to be addressed, at least not explicitly. In focusing on the making of effective, efficient policies it is possible to infer that these organisations could help strengthen the output legitimacy of the EU. However, doubts have been cast on whether guaranteeing effective outcomes is enough to bridge the EU's legitimacy gap (Schmitt \& Thomassen 1999).

The communication strategy focuses on the role of civil society in bringing citizens in to discussions about EU policies and the future direction of integration, and therefore speaks to the strengthening of input legitimacy. There is an emerging research literature which has investigated the contribution of civil society to legitimate EU governance - specifically input legitimacy (Curtin 2003; Magnette 2003; Smismans 2003) yet on the whole much less is known in this regard than is the case for the contribution of civil society to effective policies. Questions can be raised about the exact ways in which the involvement of (on the whole) EU-level organisations purporting to represent elements within civil society in processes of communicating Europe might help to bridge the gap between citizens and EU institutions, and thus strengthen the democratic legitimacy of EU governance. The rhetoric of the communication strategy (and indeed other, earlier reform discourses) assumes a high degree of mutual inclusivity between citizens and civil society, which is consistent with Nentwich's observation (1998) that most of the 'opportunity structures' for the participation of citizens in EU politics in fact favour highly organised and transnational interests; and the claim that 'citizens Europe is very much about associations rather than individual citizens' (Venables 1990: 22). Turning our empirical attention towards the organisations themselves can help 
shed more light on these issues, as the following section outlines. It becomes apparent that simply calling for the involvement of civil society in communicating Europe will not automatically provide the desired democratic outcomes.

\section{Factors affecting the communication role of organised civil society}

The role played by civil society in 'communicating Europe' that has been outlined by the Commission in the new communication strategy means that the effectiveness of this strategy will ultimately depend in part on whether civil society organisations at the EU level have the capacity and willingness to engage in communication activities. ${ }^{4}$ The rhetoric of the communication strategy is based on an assumption that civil society can help bridge the gap between citizens and EU institutions, and democratic theory supports this contention. However, empirical research on organised civil society (or organised interests) in the EU prompts speculation on the extent to which it can actually perform this bridging role and thereby enhance legitimate governance.

In order to understand more fully the possible contribution made by civil society to communicating Europe I turn empirical attention towards the organisations themselves alongside the rhetoric of the communication strategy. Discussions with EU civil society organisations which have been involved in similar legitimacy-strengthening initiatives ${ }^{5}$ highlight that their capacity and willingness to engage in these activities are affected by a range of factors, both endogenous and exogenous to them. In the following analysis I identify three factors that intervene in the relationship between the communication role played by organised civil society, and the bridging of the gap between EU governance structures and the citizens of the member states: the exact nature of the communication activities; the characteristics of civil society organisations involved; and the issue of funding.

\section{The nature of communication activities}

According to the Commission, bridging the gap between citizens and EU institutions relies on effective communication. In turn, the involvement of civil society in this 'effective communication' arguably relies on clear and focused guidelines which specify the nature and purpose of their involvement in order to enable their legitimacy-enhancing contribution. However, discussions with organisations that were involved in the debate on the future of the EU initiative revealed that organisations did not believe that the EU institutions always provided such clear statements on the exact nature of the communication activities that were envisaged, and this had problematic implications for the extent to which the objectives of the initiative were realised.

One of the problems with the debate on the future of the EU was that statements on the role of civil society generally took the form of rhetoric which was largely vague and imprecise. The Laeken declaration (made by the Heads of State and government following their meeting in December 2001) which convened the Convention on the future of the EU called for a Forum for civil society to run alongside the Convention (European Council 2001). This Forum, it suggested, would receive regular updates from the Convention, and would serve as input into the debates. However the drafters of this document (namely Belgian civil servants working during the country's presidency of the Council) had no obligation to assist with the implementation of this idea. The Secretariat of the Convention whose responsibility this became decided to delegate responsibility for the running of the Forum to the Commission (Milton \& Keller-Noëllet 2005), and the Commission developed the Forum along the same

\footnotetext{
${ }^{4}$ In turn there is the additional question of whether these activities can help to bridge the gap between citizens and EU institutions, the answer to which is beyond the scope of this paper.

${ }^{5}$ I draw upon interview data produced by fieldwork which took place between January and April 2005. The data is drawn from research on the involvement of 25 organisations that were involved in the debate on the future of the EU - specifically the Convention on the Future of the EU and the Commission's Futurum initiative.
} 
lines as its earlier 'Dialogue on Europe' initiative, a website for online discussions developed around the 2000 Intergovernmental Conference. Organisations that were following the Convention debates reported their disappointment with the way in which the promising, yet vague rhetoric on a Forum for civil society was actually implemented. As one NGO umbrella group explained: "When the Laeken conclusions came out and they said there was going to be a forum for civil society we got quite excited about that and then we got pretty dispirited when we found out it would amount to a website".

Another initiative that was designed by the Commission to encourage the participation in debates about the EU's future of a wide range of organisations and individuals from society was Futurum. Like the Convention Forum, Futurum was an online initiative which acted as a repository for material (speeches, documents and so on) relating to the broad debate on the EU's future, and provided a space for debate to take place by hosting both online and offline discussions. It invited civil society organisations to work in partnership with the EU institutions, by devoting a page on their websites to the debate, and linking these to Futurum, as a means of encouraging wider participation. Several organisations that had developed partnerships with the Futurum website admitted that they were unclear about what exactly the purpose or objectives of Futurum was, and admitted that their 'partnership' had actually involved very little tangible activity. One of the organisations that developed such a partnership, a virtual 'citizens' network' described their limited engagement with Futurum: "Back in 2001 we sent the constitution we had written to the Futurum website and that was actually our only contribution. [We] sent some documents, some analysis, what we did. To my knowledge these are the only things that have been sent to the Futurum". In this and other cases, the lack of focus meant that the outcomes of the Futurum initiative were limited.

The communication strategy demonstrates an absence of focus in terms of the intended role of civil society organisations in communication, and what it is they should be communicating. In terms of the role played by organisations, the Commission denies that its intention was to encourage civil society organisations to 'promote' the EU. Yet the Communication White Paper implies that part of the solution is in better communication of the good points of European integration: 'prosperity, solidarity and security', in other words a more effective 'selling' of the EU project. Furthermore, Plan D specifies that the content of debates should involve 'informing people about Europe's role through concrete achievements and projects' (European Commission 2005b: 5) and a call for proposals from civil society organisations issued by the Commission under Plan D outlined that the objective of the initiative was to 'seek recognition for the added value that the European Union can provide' (European Commission 2006b: 1). Nevertheless there is a certain squeamishness about explicitly saying that the objective is to inform the citizens of the benefits of the Union. Even Margot Wallström has expressly denied issuing EU 'propaganda'. Yet skirting around the issue is construed as too vague at best, and having something to hide at worst, with the end result being misunderstanding and even mistrust of the initiative.

In terms of the subject of the communication the European Commission (2006a: 2) recognises that 'Communication can never be divorced from what is being communicated', yet it says little more than what is being communicated is 'European issues' (2006a: 12). It seems naïve and unrealistic to assume that ordinary citizens would want to tell the Commission their thoughts on 'European issues', even if they could get to grips with a subject that is rather nebulous to say the least. A similar problem surrounded the debates envisaged by Plan D. Though intended to be the Commission's contribution to the 'period of reflection' called by the European Council following the referendums in France and the Netherlands, it was unclear what exactly citizens should be reflecting on (Sain ley Berry 2006) given the uncertainty that surrounded the future of the Constitutional Treaty at the time.

\section{The characteristics of civil society organisations}

The conceptualisation of civil society by the Commission is at once both broad and narrow, 
and both have potentially problematic consequences. On the one hand, as we have seen, the Commission understands civil society in terms of the organisations that populate it - in other words, as organised civil society. Democratic theorists such as Iris Marion Young (2000) see this as just one of several ways of understanding civil society. In addition to looking at the organisations or associations involved, Young combined a spatial definition with a processoriented element so that civil society could be conceptualised as a space or arena in which activities of self-organisation occurred across a range of networks or associations (Young 2000: 160). An understanding of civil society as an arena of voluntary association neither mandated nor controlled by the state is problematic in the EU context because of the high degree of institutionalisation evident in the role played by EU institutions in the formation and funding of many organisations (Greenwood 2007a: 342). In this sense, the narrow focus on civil society in terms of organisations or associations diverts attention away from the ways in which civil society at the EU level does not resemble civil society as conceptualised in democratic theory, and the consequent limitations to its legitimacy-enhancing role.

On the other hand, the definition of civil society adopted by the Commission is too broad, encompassing social partners, think-tanks and academia, professional organisations, and charities alongside non-governmental organisations (NGOs). Several civil society organisations that were involved in the debate on the future of the EU called into question this broad sectoral definition of civil society. Trade Unions questioned their status as organisations of civil society whilst one NGO federation argued that trade unions had a specific role within civil society: "I think the issue of how civil society represents or the public or certain constituencies in the public is a very important issue that we need to pay attention to in general. The trade unions and the employers have a hugely central and privileged role within the process, and I would argue again, as I've just argued with governments and media, [they] fail to translate the message or the process of the EU developments to the public; so too do the social partners abysmally fail in my view".

There was a sense that the inclusion of such a wide range of organisations under the heading of civil society, and the use of this term as though it referred to a homogenous set of actors meant that the EU institutions were not able to understand the differing capacities of organisations vis-à-vis bridging the gap between citizens and the EU. The NGOs, for example, tended to see themselves as better able to bring the voice of citizens into discussions than some of the other organisations because of their role in representing groups of citizens or their interests. More generally however, discussions with organisations posed the question of whether civil society organisations active at the EU level as a whole were suited to the task of trying to connect with citizens in the way that grass-roots organisations might. For the vast majority of them, the primary aim was to influence the policy-making process as one thinktank explained: "Mass education is not our vocation, its not our role. We try to be part of the process of explaining to people but in different ways, whether we publish papers that are readable by people other than experts or organising small events with potential multiplier effects, that sort of thing. We don't have the capacity to go and mobilise huge audiences. But other organisations can". This tended to make the organisations involved more elite-focused, than society-focused.

The experiences of organisations involved in the debate on the future of the EU demonstrates that proposals for the involvement of civil society need to be informed by an understanding of the capacities and willingness of the organisations targeted. However, it does not seem that this has been fully taken on board in the communication strategy. In addition to the task of communicating messages about the EU outwards to ordinary citizens, two further strategic principles are defined which are said to distinguish this from previous communication strategies (European Commission 2005a: 3): 'listening' and 'going local'. However, these are not necessarily complementary, and the kind of organisation that might be suited to the communication role may find it difficult to listen effectively. The EU-level umbrella organisations that the Commission has tended to favour in the past (Greenwood 2003a: 53) are by their very nature unsuited to connecting with citizens by 'going local'. A more systematic study of the role of NGOs in 'connecting' with citizens was conducted by Warleigh (2001) who found that most NGOs operating at the EU level lacked sufficiently 
democratic governance structures that would enable them to connect with citizens. This underlines the point that approaching 'civil society' wholesale hides the variations that exist between organisations and risks targeting organisations for roles to which they are unsuited.

\section{The issue of funding}

The issue of funding dominates the relationship between EU institutions and civil society organisations, and for the organisations themselves, it is often the key factor governing their interactions with the EU. It is, therefore, also crucial to understanding the role these organisations might play in bridging the gap between citizens and EU institutions. According to Greenwood (2003b: 10-22), the Commission spends $1 \%$ of the Union budget - around $€ 1$ billion annually, funding interest group activities. Many civil society organisations operating at the EU level are dependent on the Union budget for funding - and often this can be their primary source of funding.

Several organisations that were involved in the debate on the future of the EU initiative made the observation that the EU institutions wanted to draw upon the skills, expertise and contacts of civil society in trying to connect more closely with citizens - evident in both the future EU debate and the communication strategy. As such they felt that they ought to be funded for doing what amounted to the Commission's work in 'selling' the EU. Organisations were supportive of the aims of reforms which tried to bridge the gap between citizens and EU institutions, and supportive of the idea that civil society could play a role here - but as one EU-level youth organisation argued, unless they were given financial support, they simply would not have the means to contribute: "In order for the EU to say we want civil society to be involved, the main question, for [us] is that they need to be funded...that is directly in relation to communication". In contrast, a minority of voices from within civil society argued that the funding of civil society activities by the Commission compromised, if not undermined, the independence of civil society more broadly. A citizens' network (based outside Brussels) commented on "[NGOs] working in the five hundred metres around the Rond Pont Schuman [which] are just there for that reason, to get money. Any active dynamic NGO cannot accept to get into that process, and that's why they are stuck with some NGOs which are called NGOs but in fact are just trying to get cash from the EU."

The issue of funding is equally if not more relevant in the context of the new communication strategy. The Communication White Paper states that the success of the strategy will depend in part on the involvement of civil society (amongst other actors), again implying a degree of 'responsibility' for the strategy's successful implementation. Yet there remain questions about the extent to which organisations receiving funds to help 'communicate' the EU to citizens is compatible with their independence from state institutions, and their role as a counterweight to state power which is a component of their claims to legitimacy.

There are also more practical financial problems highlighted by the communication strategy. The vast majority of Union-funded projects operate under the principle of 'co-financing' which states that the Union does not finance projects up to $100 \%$ (only projects taking place outside the EU have the possibility to be financed in full). The call for proposals related to Plan D stipulated that Union funds must account for no more than $70 \%$ of the total project costs. The remaining 30\% must be secured from elsewhere (this can include working hours devoted to the project) because 'community contributions are meant to facilitate the implementation of a project which could not otherwise be implemented easily without the support of the European Union' (European Commission 2006b: 2). The ensuing need to find additional funding is a problem acutely felt by many organisations. At a Plan D consultation event hosted by the Commission Representation in the UK (Speak out Louder on Europe Conference, London, 12 June 2006) UK-based NGOs reported the difficulties they had encountered trying to get co-financing for what are essentially Commission projects. A clearer understanding of civil society on the part of the institutions might reveal that those organisations which are able to effectively 'listen' to citizens and connect with them by 'going local' are often the ones who face the greatest challenges in meeting the eligibility 
requirements to gain funding. This is also the case for the requirement in the Plan $D$ proposals that organisations must conduct their activities in multiple member states, which seems particularly at odds with the need to 'go local'.

\section{Conclusion}

How might civil society organisations contribute to strengthening the input legitimacy of the EU through communication? Light has been shed on this issue by research on the role of civil society organisations in the debate on the future of the EU initiative. This, just like the more recent communication strategy, was motivated by the perceived need to bridge the gap between citizens and the EU institutions, or in analytical terms to improve the EU's (input) legitimacy. The empirical investigation of civil society organisations involved in the Futurum and Convention debates highlights several issues relevant to the communication strategy. These issues may have implications for its prospects for success in terms of the extent to which the strategy actually ends up improving the input legitimacy of the EU.

The need for clear and focused guidelines outlining the exact role of civil society organisations relates to the way in which the objectives of the strategy are defined, and the proposals made for meeting these objectives. The experiences of organisations involved in the debate on the future of the EU demonstrated how a lack of focus could result in confusion, mismatched expectations, lack of consistency between different actors, problems with implementation, problems with evaluation and could even undermine the original objectives. Organisations felt that they were marginalised in the formal discussions of the Convention, and that their contributions were restricted to posting documents on a website. There was a sense that the rhetoric on the importance of civil society to discussions about the EU's future did not resemble the provisions that were actually made for their involvement in the debates. The failure to ratify the Constitutional Treaty following the debate on the future of the EU makes it difficult to argue that the debate was successful in bridging the gap between citizens and EU institutions. Organised civil society was supportive of the aims of the EU institutions but they acknowledged that the debate which took place was not one which involved citizens as the Laeken declaration intended, but instead the 'usual suspects': Brussels-based organisations. Without suggesting that there is a causal relationship between the overuse of rhetoric and the eventual demise of the constitution, what this does emphasise is the importance of being able to match the discourse with achievable results so as not to be left with only 'empty rhetoric'.

Similar problems of clarity overshadow the communication strategy. Paradoxically for an initiative which is all about the importance of clear and effective communication, it is not always entirely clear what the new strategy is trying to say (Sain ley Berry 2006). 'Civil society involvement' can entail many different things with varying implications for the extent to which the gap between citizens and EU institutions is bridged. For the involvement of civil society to successfully contribute to bridging this gap, the Commission needs to make a decisive comment on how exactly it should do this. If the objective is for civil society to inform people of the 'value-added' of the European Union, as the call for proposals under Plan D suggested (European Commission 2006b), this needs to be consistently acknowledged throughout other communications. This in turn will require the Commission to address the issue of funding and the case for funding in full any activities undertaken to that end.

A clear focus for a programme of reform depends upon, and in turn facilitates an understanding of civil society and the characteristics of the organisations that comprise it in the European Union. Organisations involved in the debate on the future of the EU initiative felt that the wholesale treatment of 'civil society' meant that the reform programme left no room for recognising the many differences that exist between organisations, differences which have implications for the extent to which civil society can play an effective bridging role. The empirical data presented above suggests that organisations such as think-tanks were less interested and able to engage in communication activities than, for example 
regional organisations or NGOs which were representatives of a particular sector of society. The debate initiative was problematic to the extent that it gave no scope for different organisations to use their capabilities in the way that suited them best.

The new communication strategy also deals with 'civil society' as a whole as though it was a homogenous entity, and therefore may suffer from similar limitations. On the positive side, the 2005 Action Plan acknowledged the relevance of 'going local', implying an understanding of the unique capacities of civil society organisations operating at a national or local, rather than a Brussels level, though this still does not address the functional differences between organisations. Having a clear understanding of the different types of organisation and their capacity would allow the Commission to develop more targeted proposals for engaging with civil society, which would in turn mean a clearer focus for the overall reform programme. Understanding civil society involves understanding the financial situation of the organisations that the Commission is targeting. This would allow the Union to develop a more realistic and informed approach to funding driven by the needs and requirements of the recipients as well as by the institutions' protocol.

The issue of funding is of central importance to the organisations themselves, it dominates the relationship between organisations and the EU institutions, and it is crucial to understanding the role that civil society could play in communicating Europe. Some sceptical voices from within civil society suggested that civil society organisations based in Brussels were motivated by the prospect of financial gain in the form of handouts from the Union budget for projects that amounted to 'selling' the EU's aims and objectives. Though this picture of a mercenary Brussels-based civil society is probably unjustified it does highlight the issue of whether benefiting from Union funding is compatible with bridging the gap between citizens and EU institutions. If civil society organisations are being enlisted precisely because they are independent from the institutions, their receipt of Union funds to engage in projects aimed at increasing awareness of the value-added of the EU might undermine this. On the other hand, a larger number of voices from the organisations that were involved in the debate on the future of the EU argued that if the Commission was placing part of the responsibility for bridging the gap upon civil society it ought to match this with resources.

Issues of funding are not fully resolved in the communication strategy. There is no suggestion that the Commission expects civil society organisations to promote the added value of the EU without any financial assistance. Rather, Plan D provided funding for organisations that organised debates with members of the public (European Commission 2006b). However, there is the issue of whether the requirements of the co-financing principle which govern funds preclude organisations with the potential to engage in communication activities from receiving funding. Ultimately co-financing means that larger organisations with alternate sources of funding, or staff time that can be devoted to the project, and organisations which are able to conduct their activities in multiple member states, will be the most likely to be successful in their applications. Whether these organisations are the ones that have the connection with 'ordinary citizens' necessary for facilitating their participation in debates, and whether this is compatible with the need to connect by 'going local' which is one of the 'strategic principles' outlined in the 2005 Action Plan (European Commission 2005a: 3-4) are other questions.

The rhetoric of the communication strategy calls for more effective communication between citizens and the institutions as a means of underpinning democratic governance - desirable objectives by most people's standards. But how does the rhetoric actually correspond to reality? One of the big problems with the communication strategy is that it lacks focus. For example, Plan D calls for a debate, but it is not entirely clear what exactly should be debated (EUobserver 2005). The Communication White Paper makes much of the need to listen to citizens, but it is unclear what citizens will actually be saying, or whether they will be saying anything at all. Furthermore, the communication strategy is based on the assumption that it is not the EU per se that people have a problem with, but rather the way it has been communicated (despite empirical evidence questioning whether increased knowledge and 
understanding leads to greater public support). ${ }^{6}$ Having identified communication as a means of closing the gap between citizens and EU institutions the Commission needs to ensure that the plans actually result in strengthened legitimacy. But this is tricky because the reforms are based on assumptions about civil society which are often misguided, inaccurate, or inadequate.

\section{References}

Abromeit, H. (1998). Democracy in Europe: Legitimising politics in a non-state polity. New York: Berghahn Books.

Anderson, C. \& Kaltenhaler, K. (1996). 'The Dynamics of Public Opinion toward European Integration', European Journal of International Relations, 2 (2), pp.175-99.

Beetham, D. \& Lord, C. (1998). Legitimacy and the European Union. London: Longman.

Curtin, D. (2003). 'Private Interest Representation or Civil Society Deliberation? A Contemporary Dilemma for European Union Governance', Social and Legal Studies, 12 (1), pp.55-75.

De Schutter, O. (2002). 'Europe in search of its Civil Society', European Law Journal, 8 (2), pp.198-217.

Diamond, L. (1996). 'Toward Democratic Consolidation' in L. Diamond \& M.F. Plattner (eds), The Global Resurgence of Democracy (second edition). Baltimore MD: John Hopkins University Press, pp.227-40.

Eriksen, E. O. \& Fossum, J.E. (eds) (2000). Democracy in the European Union: integration through deliberation? London: Routledge.

European Commission (1994). Information, Communication, Openness. ISEC/B25/1994. Brussels.

European Commission (2001a). European Governance. A White Paper. COM(2001) 428final. Brussels, 25 July 2001.

European Commission (2001b). Communication on a new framework for co-operation on the information and communication policy of the European Union. Brussels.

European Commission (2002). Communication on an Information and Communication Strategy for the European Union. Brussels.

European Commission (2005a). Action Plan to Improve Communicating Europe by the Commission. Brussels, 20 July 2005.

European Commission (2005b). The Commission's Contribution to the Period of Reflection and beyond: Plan D for Democracy, Dialogue and Debate. COM(2005)494final. Brussels, 13 October 2005.

European Commission (2006a). White Paper on a European Communication Policy. COM(2006) 35 final. Brussels, 1 February 2006.

European Commission (2006b). Call For Proposals - DG COMM No < A2-1/2006>. Financial support for initiatives emanating from European organisations to promote public participation in debates on topics of European interest as provided by the European Commission's Plan D for Democracy, Dialogue and Debate. Brussels.

European Commission (2007). Communicating Europe in Partnership. COM(2007) 568final. Brussels 3 October 2007.

European Council (2001). Presidency Conclusions European Council Meeting in Laeken $14^{\text {th }}$ and $15^{\text {th }}$ December 2001 (SN 300/1/01/ REV 1).

Foley, M.W. \& Edwards, B. (1997). 'Escape from Politics? Social Theory and the Social Capital Debate', American Behavioral Scientist. 40 (5), pp.550-61.

\footnotetext{
${ }^{6}$ The 'cognitive mobilisation' thesis claims that public support for integration is positively correlated with knowledge about the EU and integration (Inglehart 1970). However, Gabel's (1998) research called into question the extent to which this still holds in the EU, citing factors such as lack of empirical evidence to support the thesis, potential intervening variables such as education or date of accession, and the superiority of other explanations.
} 
Føllesdal, A. (2004). 'Legitimacy Theories of the European Union'. ARENA Working Papers. WP04/15. Oslo: ARENA.

Gabel, M. (1998). 'Public Support for European Integration: An Empirical Test of Five Theories'. Journal of Politics, 60 (2), pp.333-54.

Greenwood, J. (2003a). 'The World of EU NGOs and Interest Representation'. NGOs, Democratisation and the Regulatory State. London: European Policy Forum, pp.51-64.

Greenwood, J (2003b). Interest Representation in the European Union. Basingstoke, Macmillan.

Greenwood, J. (2007a). 'Organized Civil Society and Democratic Legitimacy in the EU', British Journal of Political Science, 37, pp.333-57.

Greenwood, J (2007b). Interest Representation in the European Union (Second edition). Basingstoke: Macmillan Palgrave.

Hooghe, L. (2003). 'Europe Divided? Elite vs. public opinion on European Integration'. European Union Politics, 4, pp.251-304.

Inglehart, R. (1970). 'Cognitive Mobilization and European Identity', Comparative Politics 3 (1), pp.45-70.

Lindberg, L. \& Scheingold, S. (eds) (1971). Regional integration theory and research. Cambridge, MA: Harvard University Press.

Magnette, P. (2003). 'European Governance and Civic Participation: Beyond Elitist Citizenship?', Political Studies, 51 (1), pp.144-60.

Mazey, S. \& Richardson, J (eds) (1993). Lobbying in the European Community. Oxford: Oxford University Press.

Mazey, S. \& Richardson, J (1999). 'Interests' in L. Cram; D. Dinan \& N. Nugent (eds), Developments in the European Union. Basingstoke: Macmillan, pp.105-29.

Milton, G. \& Keller-Noëllet, J. (2005). The European Constitution: its Origins, Negotiations and Meaning. London: John Harper.

Nentwich, M. (1998). 'Opportunity structures for citizens' participation. The case of the European Union', in A. Weale \& M. Nentwich (eds), Political Theory and the European Union: Legitimacy, Constitutional Choice and Citizenship. London: Routledge, pp.12540.

Niedermayer, O. \& Sinnott, R. (1995). 'Introduction', in O. Niedermayer \& R. Sinnott (eds), Public Opinion and Institutionalised Governance. Oxford: Oxford University Press, pp.15.

Sain ley Berry, P. (2006). 'Communication strategy is missing the point', available at: http://euobserver.com/?aid=20829, accessed 3 February 2006.

Scharpf, F.W. (1997). 'Economic integration, democracy and the welfare state'. Journal of European Public Policy, 4, pp.520-38.

Scharpf, F.W. (1998). Governing in Europe: Effective and Democratic?. Oxford: Oxford University Press.

Schmitt, H. \& Thomassen, J. (1999). 'Conclusion: Political Representation and Legitimacy in the European Union', in J. Thomassen \& H. Schmitt (eds), Political Representation and Legitimacy in the European Union. Oxford: Oxford University Press.

Smismans, S. (2003) 'European Civil Society; Shaped by Discourses and Institutional Interests'. European Law Journal, 9 (4), pp.473-95.

Smismans, S. (ed.) (2006). Civil Society and Legitimate European Governance. Cheltenham: Edward Elgar.

Venables, T. (1990). 'European Citizens' Action Service', in C. McConnell (ed.), Citizens' Europe? Community Development in Europe Towards 1992. Colchester: Community Development Foundation.

Warleigh, A. (2001). 'Europeanizing Civil Society: NGOs as Agents of Political Socialization', Journal of Common Market Studies. 39 (4), pp.619-39.

Warleigh, A. \& Fairbrass, J. (eds) (2002). Influence and Interests in the European Union: The New Politics of Persuasion and Advocacy. London: Taylor \& Francis.

Young, I.M. (2000). Inclusion and Democracy. Oxford: Oxford University Press. 